\title{
Variability Studies on Seed Attributes of Prosopis juliflora in South India
}

\author{
S. Reeja*, B. Palanikumaran and K.T. Parthiban \\ Forest College and Research Institute, Dulapally, Telangana, India \\ *Corresponding author
}

A B S T R A C T

\begin{tabular}{|c|}
\hline $\begin{array}{l}\text { K e y w o r d s } \\
\text { Prosopis juliflora, Seed } \\
\text { parameters, Variability } \\
\text { and germination percent }\end{array}$ \\
\hline Article Info \\
\hline $\begin{array}{l}\text { Accepted: } \\
10 \text { February } 2018 \\
\text { Available Online: } \\
10 \text { March } 2018\end{array}$ \\
\hline
\end{tabular}

\section{Introduction}

People in the arid zones of South India are mainly dependant on the available scanty resources that the ecosystem provides. The livelihood of the people is made even worse by land degradation caused by over exploitation and the harsh climatic conditions. Economically backward People in this region largely depend on fuelwood and livestock to meet out their ends. The need for a multipurpose tree that caters for fooder, fuel and timber with additional value added derivatives, if any, are considered a natural boon to this society. Fortunately these tracts are largely blessed (though alien and invasive) with the lush growth of ever green spiny mesquite trees, which is seen as a potential and promising package for transforming the lives of the poor for the better in these regions.
Prosopis juliflora is one of the most economically and ecologically important tree species in arid and semi-arid zones of the world and commonly planted in adverse sites where, availability of macro/micro nutrient have potentially been found limiting its growth (Jarrell et al., 1982). Certain physical and physiological characteristics in the ancestral stock may have given prosopis a comparative advantage in such dry zones, allowing for rapid colonization.

Experience with hardy often fast growing tree species, which have been extensively planted as exotic has demonstrated that studies on the genetic variation are critical to continuing success. Prosopis species are essentially outcrossers, which results in a high degree of individual tree variability providing great potential for improving selected characters 
once they are genetically identified. Possibly one of the most important observations to date is the extensive within family variation suggesting that the critical unit for early improvement is the individual tree rather than family or provenance.

Success in establishment and productivity of forest tree plantations is determined largely by the species used and source of seed within the population (Larsen, 1954; Callaham, 1964 and Lacaze, 1978).

Seed is one of the important inputs for forest nursery production and plantation establishment (Lauridsen and Olesen, 1990). The seeds used for large-scale plantation programmes must be genetically superior to produce timber of higher volume in a shorter period of time. The knowledge available at present on the extent of variation present in the populations of different seed sources and provenances is insufficient to proceed any kind of improvement studies in Prosopis juliflora. Hence the present study was initiated to provide resourceful information on variability aspects of seed traits.

\section{Materials and Methods}

\section{Location of the study area}

The experimental material for the present study consisted of 30 seed sources of Prosopis juliflora collected from 30 districts of Tamilnadu. The regulations for seed source sampling concerning minimum number of trees and distance between parent trees, were followed (Lauridsen and Olesen, 1990). Seeds from individual trees were mixed and used as seed source in the present investigation. These experiments were carried out at Forest College and Research Institute, Mettupalayam (11 ${ }^{\circ} 19^{\prime}$ $\mathrm{N} ; 7^{\circ} 56^{\prime} \mathrm{E}$; $300 \mathrm{MSL}$ ). The actual locations of the seed sources and their geographic features are presented in Table 1.

\section{Determination of variability studies in seed parameters}

The physical characters of seed viz. 2D surface area $\left(\mathrm{cm}^{2}\right)$, perimeter $(\mathrm{cm})$, seed length, seed width and seed aspect ratio were measured using image analyser (Q Win $500 \mathrm{MC}+$ Leica, UK). The seed parameter studies were carried out with a random sample of 20 seeds from each seed source with six replications. Seeds of the sample quantity were spread on a glass platform of macro viewer in replication wise and images were captured and taken into the software called Quantimet $500+$ or Q Win. The captured images were calibrated to actual scale. The Q Win identifies the object based on our specification for seed colour. The Q Win measures 2D surface area, perimeter, seed length, seed width and seed aspect ratio of the identified image of the seeds. The seed parameters viz., 2D surface area $\left(\mathrm{cm}^{2}\right)$, Perimeter $(\mathrm{cm})$, Length $(\mathrm{cm})$, Width $(\mathrm{cm})$, Aspect ratio, Hundred seed weight (g), Pod length (cm.), Number of seeds/pod, Viability percentage, Germination percentage were studied.

\section{Results and Discussion}

The basic aim for any tree improvement programme is the exploitation of available natural variability within the species. The tree improvement programme must always be preceded by the estimation of the extent of variability available in the natural population. The pattern of variability helps to design the testing procedure and identify the superior genotypes based on the described tracts. The largest, cheapest and fastest gains in most forestry tree improvement programmes will accrue if use of suitable species and seed sources within species is assured (Zobel and Talbert, 1984). The choice of provenance and seed source is important since it decides the genetic quality and the physiological potential of the seed. Seeds are influenced by their 
place of origin (Heydecker, 1972), especially due to environmental variations in latitude, altitude, rainfall, temperature, moisture and the external factors (Shivakumar and Bannerjee, 1986). The seed source variations were reported in many tree species (Bagchi and Dobriyal, 1990; Mishra and Bannerjee, 1995; Thapliyal and Dhiman, 1997; Pathak, 1998; Mohit Gera et al., 1999) and were dictated by environmental and edaphic factors. This may also be due to altitudinal variation (Barnett and Farmer, 1978) or region of collection (Bonner, 1984).

The present study revealed that significant amount of variability exists among different seed sources in all the seed characters investigated viz., seed 2D surface area, seed perimeter, seed length, seed width, seed aspect ratio, hundred seed weight, pod length, number of seeds per pod, viability percentage and germination percentage. The seed source Keezhakarai registered the highest and significant values for seed 2D surface area $\left(0.061 \mathrm{~cm}^{2}\right)$, seed perimeter $(1.456 \mathrm{~cm})$, seed length $(0.365 \mathrm{~cm})$ and seed weight $(0.255 \mathrm{~cm})$ (Table 2). Similarly, superiority in aspect ratio was recorded by Salem (0.825) and Nagercoil (0.795) seed source. Tirunelveli seed source exhibited significant values for 100 seed weight $(3.555 \mathrm{~g})$. The variation in seed physical characters must be attributable to differences in physiographic, edaphic and climatic factors (Mathur et al., 1984; Padmini and Bannerjee, 1986).

In the present study, seeds were collected from 30 different sources, which had the wide latitude ranging from $8^{\circ} 11^{\prime} \mathrm{N}$ to $12^{\circ} 55^{\prime} \mathrm{N}$ and the longitude from $77^{\circ} 00^{\prime} \mathrm{E}$ to $80^{\circ} 01^{\prime} \mathrm{E}$, which might be the reason for the variability in seed parameters. Such variation in seed parameters were also earlier well documented in Acacia auriculiformis and A. mangium (Hegde et al., 2000), A. nilotica (Vanangamudi et al., 1998), Albizia lebbeck
(Radhakrishnan, 2001), Tectona grandis (Parthiban, 2001), Tamarindus indica (Divakara, 2009), Simarouba glauca (Masilamani et al., 2004), Terminalia (Srivastav and Thangavelu, 2003), Albizia chinensis (Dhanai et al., 2003) and Acacia catechu (Rajesh Kumar et al., 2004). In the current investigation the seed source viz., Sivaganga scored higher values for pod length $(23.05 \mathrm{~cm})$. The number of seeds per pod is found to be more in Rameshwaram pods (29.00). Similarly viability percentage is higher for Tuticorin seed source $(94.50 \%)$ followed by Tirunelveli (93.00), Rameshwaram and Ramnad (92.00\%). Higher germination percentage is recorded by Pollachi $(90.5 \%)$ and Rameshwaram (92.00\%) seed sources followed by Theni $(88.00 \%)$, Coimbatore $(87.50 \%)$ and Ramnad $(87.5 \%)$ (Table 2; Fig. 1). Genetic factors influence is an important role in deciding germination, survival and establishments of seeds. Variation in seed germination due to seed sources were also reported in Acacia auriculiformis and A. mangium (Ramakrishnan Hegde et al., 2000), Acacia catechu (Rajesh Kumar et al., 2004), Casuarina equisetifolia (Jambulingam, 1990), Dalbergia latifolia (Mohit Gera et al., 1999), and Tectona grandis (Masilamani et al., 1999; Parthiban, 2001).

The choice of provenance and seed source is important since it decides the genetic quality and the physiological potential of the seed. Genetic factors coupled with environmental factors influence germination, survival and establishment behavior of seed. The study confirms the enormous variation that exists in nature in different seed sources for various seed characters of Prosopis juliflora. The present study revealed that seed sources from Tuticorin, Rameshwaram, Ramnad and Keezhakarai exhibits significant amount of variability in all the seed characters investigated. 
Table.1 Details of the seed sources

\begin{tabular}{|c|c|c|c|}
\hline $\begin{array}{c}\text { Source } \\
\text { No. }\end{array}$ & Seed source & Latitude & Longitude \\
\hline $\mathrm{S}_{1}$ & Bodi & $10^{\circ} 01^{\prime} \mathrm{N}$ & $77^{\circ} 00^{\prime} \mathrm{E}$ \\
\hline $\mathrm{S}_{2}$ & Vellore & $12^{\circ} 55^{\prime} \mathrm{N}$ & $79^{\circ} 11^{\prime} \mathrm{E}$ \\
\hline $\mathrm{S}_{3}$ & Madurai & $9^{\circ} 58^{\prime} \mathrm{N}$ & $78^{\circ} 10^{\prime} \mathrm{E}$ \\
\hline $\mathrm{S}_{4}$ & Theni & $9^{\circ} 68^{\prime} \mathrm{N}$ & $79^{\circ} 86^{\prime} \mathrm{E}$ \\
\hline $\mathrm{S}_{5}$ & Kancheepuram & $12^{\circ} 50^{\prime} \mathrm{N}$ & $79^{\circ} 45^{\prime} \mathrm{E}$ \\
\hline $\mathrm{S}_{6}$ & Dindigul & $10^{\circ} 22^{\prime} \mathrm{N}$ & $78^{\circ} 00^{\prime} \mathrm{E}$ \\
\hline $\mathrm{S}_{7}$ & Chengam & $12^{\circ} 15^{\prime} \mathrm{N}$ & $79^{\circ} 07^{\prime} \mathrm{E}$ \\
\hline $\mathrm{S}_{8}$ & Tuticorin & $8^{\circ} 48^{\prime} \mathrm{N}$ & $78^{\circ} 11^{\prime} \mathrm{E}$ \\
\hline $\mathrm{S}_{9}$ & Pollachi & $10^{\circ} 39^{\prime} \mathrm{N}$ & $77^{\circ} 03^{\prime} \mathrm{E}$ \\
\hline $\mathrm{S}_{10}$ & Tirunelveli & $8^{\circ} 44^{\prime} \mathrm{N}$ & $77^{\circ} 44^{\prime} \mathrm{E}$ \\
\hline $\mathrm{S}_{11}$ & Coimbatore & $11^{\circ} 00^{\prime} \mathrm{N}$ & $77^{\circ} 10^{\prime} \mathrm{E}$ \\
\hline $\mathrm{S}_{12}$ & Villupuram & $11^{\circ} 57^{\prime} \mathrm{N}$ & $79^{\circ} 32^{\prime} \mathrm{E}$ \\
\hline $\mathrm{S}_{13}$ & Tirupathur & $11^{\circ} 68^{\prime} \mathrm{N}$ & $79^{\circ} 25^{\prime} \mathrm{E}$ \\
\hline $\mathrm{S}_{14}$ & Sivaganga & $10^{\circ} 62^{\prime} \mathrm{N}$ & $79^{\circ} 15^{\prime} \mathrm{E}$ \\
\hline $\mathrm{S}_{15}$ & Trichy & $10^{\circ} 50^{\prime} \mathrm{N}$ & $78^{\circ} 46^{\prime} \mathrm{E}$ \\
\hline $\mathrm{S}_{16}$ & Pudukottai & $10^{\circ} 23^{\prime} \mathrm{N}$ & $78^{\circ} 52^{\prime} \mathrm{E}$ \\
\hline $\mathrm{S}_{17}$ & Chennai & $12^{\circ} 42^{\prime} \mathrm{N}$ & $80^{\circ} 01^{\prime} \mathrm{E}$ \\
\hline $\mathrm{S}_{18}$ & Sivakasi & $9^{\circ} 27^{\prime} \mathrm{N}$ & $77^{\circ} 36^{\prime} \mathrm{E}$ \\
\hline $\mathrm{S}_{19}$ & Cuddalore & $11^{\circ} 43^{\prime} \mathrm{N}$ & $76^{\circ} 58^{\prime} \mathrm{E}$ \\
\hline $\mathrm{S}_{20}$ & Virudhunagar & $9^{\circ} 35^{\prime} \mathrm{N}$ & $77^{\circ} 57^{\prime} \mathrm{E}$ \\
\hline $\mathrm{S}_{21}$ & Aruppukkottai & $9^{\circ} 31^{\prime} \mathrm{N}$ & $78^{\circ} 08^{\prime} \mathrm{E}$ \\
\hline $\mathrm{S}_{22}$ & Erode & $11^{\circ} 20^{\prime} \mathrm{N}$ & $77^{\circ} 46^{\prime} \mathrm{E}$ \\
\hline $\mathrm{S}_{23}$ & Perambalur & $11^{\circ} 14^{\prime} \mathrm{N}$ & $78^{\circ} 56^{\prime} \mathrm{E}$ \\
\hline $\mathrm{S}_{24}$ & Keezhakarai & $9^{\circ} 14^{\prime} \mathrm{N}$ & $78^{\circ} 50^{\prime} \mathrm{E}$ \\
\hline $\mathrm{S}_{25}$ & Sankarankoil & $9^{\circ} 10^{\prime} \mathrm{N}$ & $77^{\circ} 35^{\prime} \mathrm{E}$ \\
\hline $\mathrm{S}_{26}$ & Salem & $11^{\circ} 39^{\prime} \mathrm{N}$ & $78^{\circ} 12^{\prime} \mathrm{E}$ \\
\hline$S_{27}$ & Rameshwaram & $9^{\circ} 17^{\prime} \mathrm{N}$ & $79^{\circ} 22^{\prime} \mathrm{E}$ \\
\hline $\mathrm{S}_{28}$ & Dharmapuri & $12^{\circ} 08^{\prime} \mathrm{N}$ & $78^{\circ} 13^{\prime} \mathrm{E}$ \\
\hline $\mathrm{S}_{29}$ & Ramnad & $9^{\circ} 22^{\prime} \mathrm{N}$ & $78^{\circ} 52^{\prime} \mathrm{E}$ \\
\hline $\mathrm{S}_{30}$ & Nagercoil & $8^{\circ} 11^{\prime} \mathrm{N}$ & $77^{\circ} 29^{\prime} \mathrm{E}$ \\
\hline
\end{tabular}


Table.2 Seed source variations in seed physical characters

\begin{tabular}{|c|c|c|c|c|c|c|c|c|c|c|}
\hline $\begin{array}{c}\text { Seed } \\
\text { sources }\end{array}$ & $\begin{array}{l}\text { 2D surface area } \\
\left(\mathrm{cm}^{2}\right)\end{array}$ & $\begin{array}{l}\text { Perimeter } \\
\quad(\mathrm{cm})\end{array}$ & $\begin{array}{l}\text { Length } \\
(\mathrm{cm})\end{array}$ & $\begin{array}{l}\text { Width } \\
(\mathrm{cm})\end{array}$ & $\begin{array}{l}\text { Aspect } \\
\text { ratio }\end{array}$ & $\begin{array}{c}100 \text { seed weight } \\
(\mathrm{g})\end{array}$ & $\begin{array}{l}\text { Pod length } \\
\quad(\mathrm{cm})\end{array}$ & $\begin{array}{l}\text { No. of seeds/ } \\
\text { pod }\end{array}$ & $\begin{array}{c}\text { Viability } \\
(\%)\end{array}$ & $\begin{array}{c}\text { Germination } \\
\%\end{array}$ \\
\hline $\mathrm{S}_{1}$ & 0.050 & 1.300 & 0.315 & 0.240 & 0.765 & $3.260 *$ & 18.000 & 24.000 & 86.500 & 82.000 \\
\hline $\mathrm{S}_{2}$ & 0.029 & 0.775 & 0.235 & 0.170 & 0.725 & 2.745 & 14.250 & 22.000 & 87.500 & 76.500 \\
\hline $\mathrm{S}_{3}$ & 0.050 & 1.300 & $0.335 *$ & 0.240 & 0.740 & $3.195 *$ & $22.500 *$ & 23.000 & $92.500 *$ & 86.500 \\
\hline $\mathrm{S}_{4}$ & 0.035 & 0.940 & 0.260 & 0.195 & 0.765 & 3.045 & 18.000 & 23.500 & 82.500 & $88.000^{*}$ \\
\hline $\mathrm{S}_{5}$ & 0.051 & 1.200 & $0.345^{*}$ & 0.245 & 0.745 & 2.730 & 13.050 & 19.000 & 77.000 & 77.500 \\
\hline $\mathrm{S}_{6}$ & 0.039 & $1.350 *$ & 0.310 & 0.210 & 0.685 & 2.790 & 19.450 & 23.000 & $90.000 *$ & 84.000 \\
\hline $\mathrm{S}_{7}$ & 0.039 & 1.100 & 0.280 & 0.205 & 0.755 & 2.750 & 16.800 & 25.500 & 88.000 & 72.500 \\
\hline $\mathrm{S}_{8}$ & $0.052 *$ & 1.130 & 0.295 & 0.190 & 0.645 & 3.330 & $21.300^{*}$ & 26.500 & $94.500^{*}$ & $87.500 *$ \\
\hline $\mathrm{S}_{9}$ & 0.032 & 1.025 & 0.260 & 0.205 & 0.775 & 2.915 & 18.750 & 24.500 & $93.000 *$ & $90.500 *$ \\
\hline $\mathrm{S}_{10}$ & 0.042 & 1.050 & 0.295 & 0.225 & 0.745 & $3.555 *$ & $22.650 *$ & 22.500 & 87.500 & 79.000 \\
\hline $\mathrm{S}_{11}$ & $0.053 *$ & $1.450^{*}$ & 0.330 & 0.245 & 0.730 & $3.215^{*}$ & $20.750 *$ & 24.000 & 84.500 & $87.500^{*}$ \\
\hline $\mathrm{S}_{12}$ & 0.034 & 0.845 & 0.260 & 0.190 & 0.685 & 2.990 & 14.600 & 25.500 & 79.000 & 81.000 \\
\hline $\mathrm{S}_{13}$ & 0.040 & 1.000 & 0.270 & 0.210 & 0.770 & 2.895 & 18.100 & 23.500 & 81.500 & 76.000 \\
\hline $\mathrm{S}_{14}$ & 0.048 & 1.250 & 0.300 & 0.170 & 0.605 & $3.470 *$ & $23.050 *$ & 25.000 & 78.500 & 82.000 \\
\hline $\mathrm{S}_{15}$ & 0.043 & 1.100 & 0.310 & 0.205 & 0.655 & 2.690 & 17.425 & 23.500 & 74.000 & 82.500 \\
\hline $\mathrm{S}_{16}$ & $0.052 *$ & 1.300 & 0.325 & $0.260 *$ & $0.790 *$ & 2.660 & 16.700 & 23.000 & 67.500 & 75.000 \\
\hline $\mathrm{S}_{17}$ & 0.043 & 1.100 & 0.300 & 0.215 & 0.720 & 2.795 & 12.450 & 17.000 & 76.500 & 80.000 \\
\hline $\mathrm{S}_{18}$ & 0.044 & 1.050 & 0.295 & $0.255^{*}$ & 0.780 & 2.550 & 16.020 & 21.350 & 74.500 & 84.500 \\
\hline $\mathrm{S}_{19}$ & 0.041 & 0.995 & 0.275 & 0.210 & 0.750 & 2.765 & 18.900 & 20.500 & 71.000 & 73.500 \\
\hline $\mathrm{S}_{20}$ & 0.032 & 0.795 & 0.255 & 0.170 & 0.655 & 2.870 & 17.900 & 25.000 & 81.000 & 77.500 \\
\hline $\mathrm{S}_{21}$ & 0.043 & 1.150 & 0.290 & 0.225 & 0.765 & 2.865 & 19.385 & $27.500 *$ & 76.000 & 86.500 \\
\hline $\mathrm{S}_{22}$ & 0.051 & 1.300 & 0.330 & 0.235 & 0.710 & 2.740 & 13.885 & 24.500 & 86.000 & 81.500 \\
\hline $\mathrm{S}_{23}$ & 0.032 & 0.815 & 0.250 & 0.175 & 0.695 & 2.680 & 16.150 & 20.000 & 72.000 & 77.000 \\
\hline $\mathrm{S}_{24}$ & $0.061 *$ & $1.456 *$ & $0.365^{*}$ & $0.255^{*}$ & 0.720 & $3.060 *$ & 14.250 & 26.000 & 83.500 & 84.000 \\
\hline $\mathrm{S}_{25}$ & 0.033 & 0.865 & 0.240 & 0.185 & 0.780 & 2.850 & 21.650 & 24.500 & 85.000 & 82.500 \\
\hline $\mathrm{S}_{26}$ & 0.045 & 1.150 & 0.295 & 0.245 & $0.825^{*}$ & 2.710 & $15.345^{*}$ & 20.000 & 70.000 & 80.500 \\
\hline $\mathrm{S}_{27}$ & 0.047 & 1.150 & 0.310 & 0.230 & 0.750 & $3.235^{*}$ & 12.250 & $29.000 *$ & $92.000 *$ & $90.000 *$ \\
\hline $\mathrm{S}_{28}$ & 0.044 & 1.250 & 0.300 & 0.230 & $0.785^{*}$ & 2.625 & 16.300 & 24.500 & 70.000 & 71.500 \\
\hline $\mathrm{S}_{29}$ & 0.040 & 1.050 & 0.295 & 0.205 & 0.695 & $3.350 *$ & 14.150 & 26.500 & $92.000 *$ & $87.500^{*}$ \\
\hline $\mathrm{S}_{30}$ & 0.049 & 1.200 & 0.310 & 0.245 & $0.795^{*}$ & 2.920 & 19.500 & 23.000 & 86.500 & 76.500 \\
\hline Mean & 0.041 & 1.115 & 0.294 & 0.216 & 0.704 & 2.942 & 17.450 & 23.578 & 81.983 & 81.367 \\
\hline SEd & 0.005 & 0.112 & 0.018 & 0.016 & 0.038 & 0.056 & 1.186 & 1.714 & 3.686 & 2.528 \\
\hline $\mathrm{CD}$ & 0.010 & 0.229 & 0.036 & 0.033 & 0.077 & 0.115 & 2.425 & 3.505 & 7.540 & 5.170 \\
\hline
\end{tabular}

* Significant at 5\% level 
Fig.1 Seed source variation for germination (\%)

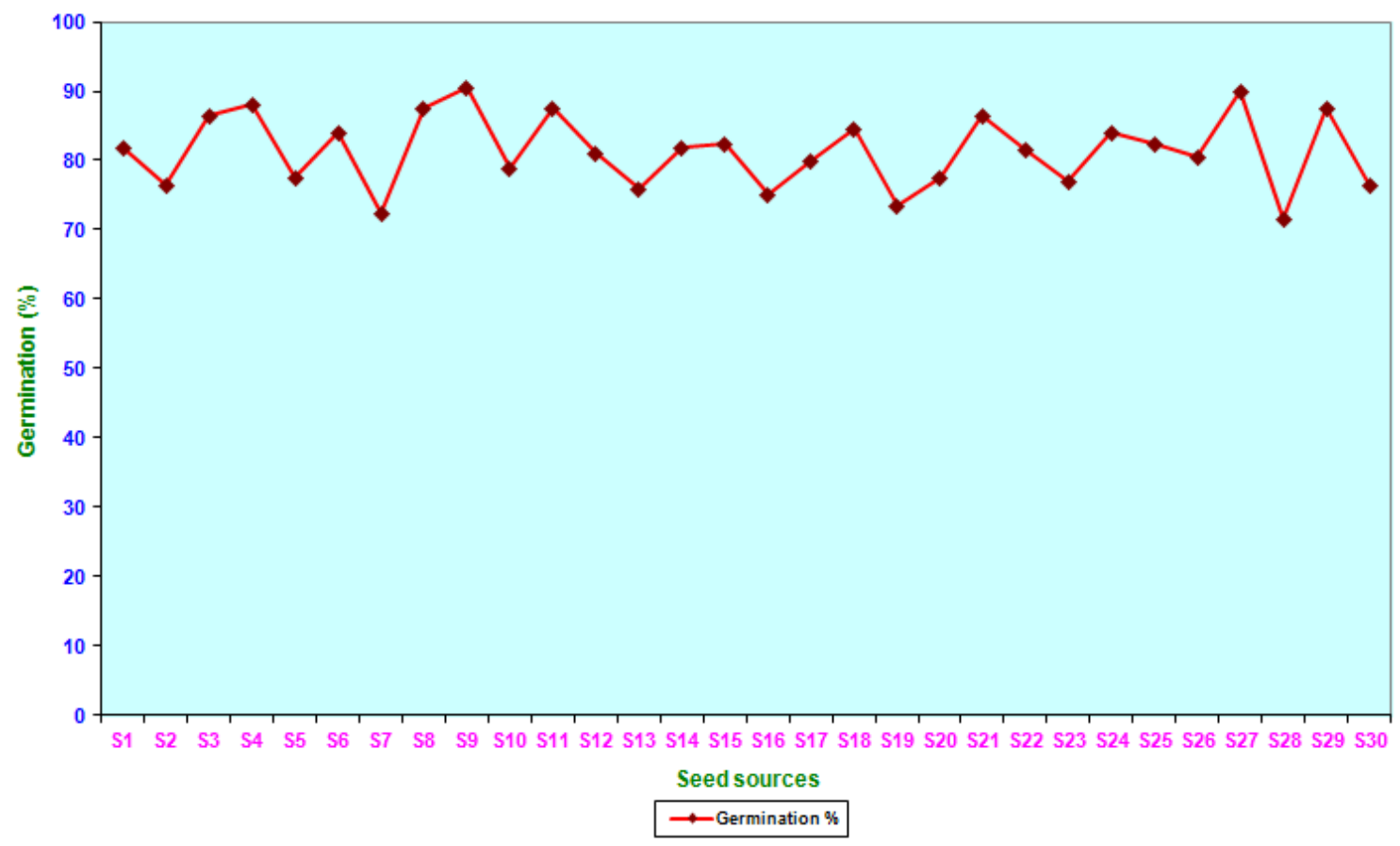

\section{Acknowledgement}

The authors rightfully acknowledge State Land Use Board for providing financial grants to carry out the research and Tamil Nadu Agricultural University for providing the opportunity.

\section{References}

Bagchi, S.K. and N.D. Dobriyal. 1990. Provenance variation in seed parameters of Acacia nilotica. Indian Forester, 116: 958-961.

Bagchi, S.K. and N.D. Dobriyal. 1990. Provenance variation in seed parameters of Acacia nilotica. Indian Forester, 116: 958-961.

Bagchi, S.K. and V.P. Sharma. 1989.

Biometrical studies on seed characters of Santalum album L. Silvae Genetica, 38(3-4): 152-153.

Barnett, P.E. and R.E. Farmer. 1978. Altitudinal variation in germination characteristics of yellow poplar in the Southern Appalachians. Silvae Genetica, 27(3-4): 101-104.

Bonner, F.T. 1984. Glossary of seed germination terms for tree seed workers, USDA Forest Service. Gen. Tech. Rep., Southern Forest Experiment Station, Starkville, Mississippi, USA. pp 30-49.

Callaham, R.Z. 1964. Provenance researchInvestigations of genetic diversity associated with geograph. Unasylva, 18 (2-3): 40-50, 73-74.

Deepak Chopra and M.S. Hooda. 2001. Genetic variability and correlation studies in seed traits of mesquite (Prosopis juliflora (SW) DC.). Indian Journal of Forestry, 24(2): 162-165.

Dhanai, C.S., A.K. Uniyal and N.P. Todaria. 2003. Provenance variation in pod and seed characteristics of Albizia chinensis (Osbeck) in Western Himalaya. Indian Journal of Forestry, 26(3): 201-207.

Divakara, B.N. 2009. Variation and Character Association for various Pulp 
Biochemical traits in Tamarindus indica L. Indian Forester, 135(1):99-110.

Goulden, C.H. 1952. Some distance properties of latent root and vector methods used in multivariate analysis. Biometrika, 53: 325-338.

Heydecker, W. 1972. Vigour. In: "Viability of seeds". (Ed. E.H. Roberts). Chapman Hall, London. pp 209-252.

ISTA. 1999. International rules for seed testing. Seed Sci. Technol., 27: Supplement rules.

Jambulingam, R. 1990. Recent development in research on Casuarina in Tamil Nadu. Variation in population advances in Casuarina research and utilization. In: Proc. of the Second International Workshop, Cairo, Egypt, January. pp 15-20.

Jarrell, W.M., R.A. Virginia, D.H. Kohl, G. Shearer, B.A. Bryan, P.W. Rundel, E.T. Nilsen and M.R. Sharifi. 1982. Symbiotic nitrogen fixation by mesquite and its management implications. Pp. R1-R12. In: Mesquite utilization. (Ed.) H.W. Parker. Texas Tech University, Lubbock, Texas,

Lacaze, J.F. 1978. Advances in species and provenance selection. Unasylva, 30 (119-120): 17-20.

Larsen, C.S. 1954. Provenance testing and forest tree breeding proceedings. $11^{\text {th }}$ Congress IUFRO Rome p. 467-473.

Lauridsen, E.B., K. Olesen. 1990. Identification establishment and management of seed sources. Danida Forest Seed Centre. Lecture Note. B-2. P.20.

Masilamani, P., C. Dharmalingam and K. Annadurai. 1999. Provenance variation in seed and seedling attributes of teak (Tectona grandis Linn. f.). Paper presented in National Symposium on "Forestry Towards $21^{\text {st }}$ Century" held at Tamil Nadu Agricultural University, Coimbatore, September 27-28.
Masilamani, P, K. Kumaran, K. Annadurai, J. Balamurugan, I. Sekar.2004. Research Notes on Effect of Age of Mother Tree on Germination and Initial Vigour of Simarouba glauca DC. Indian Forester, 130(5).

Mathur, R.S., K.K. Sharma and M.M.S. Rawat. 1984. Germination behaviour of various provenances of Acacia nilotica spp. indica. Indian Forester, 111: 435449.

Mishra, C.M. and A.C. Banerjee. 1995. Provenance variation in Casuarina species with reference to germination and growth. J. Trop. For., 11(3): 209211.

Mohit Gera, N. Gera and H.S. Ginwal. 1999. Seed source variation in germination and early growth among ten indigenous populations of Dalbergia sissoo Roxb. Indian Forester, 125(12): 1190-1197.

Padmini, S. and A.C. Banerjee. 1986. Provenance trails of Acacia nilotica. J. Tree Sci., 5: 53-56.

Parthiban, K.T. 2001. Seed source variations, molecular characterization and clonal propagation in teak (Tectona grandis Linn f.). Ph.D. Thesis, Tamil Nadu Agricultural University, Coimbatore.

Pathak, N.N. 1998. Field evaluation and selection of Acacia nilotica provenances. J. Trop. For., 14(IV): 197.

Radhakrishnan, S. 2001. Genetic divergence and DNA based molecular characterization in Albizia lebbeck (L.) Benth. Ph.D. (For.) Thesis, Tamil Nadu Agricultural University, Coimbatore.

Rajesh Kumar, S. Nautiyal, Pankaj Kumar and Anjali Bahuguna. 2004. Seed source variation in khair (Acacia catechu Willd.). Indian Forester, May: 530-536.

Ramakrishna Hegde, Varghese, M., Padmini, S. and R.G.S. Jayaraj. 2000. Variation in seed and seedling characteristics of Acacia mangium Willd and $A$. 
auriculiformis A. Cunn. Ex. Benth. Indian Forester, 126(4): 382-387.

Shivakumar, P. and A.C. Banerjee. 1986. Provenance trials of Acacia nilotica. J. Tree Sci., 5(1): 53-56.

Srivastava and K. Thangavelu. 2003. Genetic variability and co-heritability in Terminalia (Section: Pentaptera) for fruit (seed) characters. Indian Journal of Forestry, 26(1): 59-63.

Thapliyal, R.C. and R.C. Dhiman. 1997. Geographic variation in seed and seedling characteristics in Pinus roxburghii from Himachal Pradesh. Ann. For., 5(2): 140-145.

Vanangamudi, K., R. Umarani, A. Bharathi and A. Venkatesh. 1998. Effect of seed source on physical and physiological qualities of Acacia nilotica seeds. Seed Res., 26(2): 114-116.

Wright, S. 1921. Correlation and causation. J. Agric. Res., 20: 557-585.

Zobel, B.J. and J. Talbert. 1984. Applied tree improvement. John Wiley \& Co. 503 p.

\section{How to cite this article:}

Reeja, S., B. Palanikumaran and Parthiban, K.T. 2018. Variability Studies on Seed Attributes of Prosopis juliflora in South India. Int.J.Curr.Microbiol.App.Sci. 7(03): 1216-1223. doi: https://doi.org/10.20546/ijcmas.2018.703.143 